\title{
編集方針の変更について
}

\section{農業情報利用研究会編集委員長 二宮正士}

本誌の冒頭に会長よりの報告がありますよう に, 農業情報利用研究会も時代の要請を受け大き く変わろうとしています．まだ，会がどのような 形に変身するかについて確定しているわけではあ りませんが, 編集委員会もそのような背景のも と，これらかの編集方針について議論を重ねてき ました．その中での論点には大別してふたつあり ます. 一つは, 会誌の質の向上とより高頻度での 発行, 二つは編集体制の見直しです。

まず，雑誌の質の向上とより高頻度での発行で すが, これには会の活動の顔としての会誌を充実 してより多くの会員の参集を促すと同時に，本会 会員から，より上質の解説や論文等を集め易くす るねらいがあります。そして, 内容が良くなれば さらに良質の原稿が集まり易くなるという相乗効 果をねらっています。この事をより効果的にする には，会誌の発行頻度を上げる必要があります。 現在, 農業情報研究と農業情報利用を合わせれば 年間 4 ? 5 号を発行していますが, 全く性格の異 なるそれぞれは年 2 回程度に過ぎず，急速に進展 する分野を対象とする会の定期刊行物としてはい かにも少ないというのが現状です．この頻度の低 さがより上質の記事や論文を集める妨げになって いたことも否めません.

本来, それぞれの会誌の発行頻度を上げるべき ですが, 編集事務の增大に加えコスト的問題から 断念せざるを得ないのが現状です．電子ジャーナ ル化など様々な意見がありましたが，最終的に二 誌を合本化し年 4 回発行することとし，さらに可 能ならその形式で発行回数を増やすという方針が 決まりました．また，そして単に二誌を合本にす るだけでなく, 記事内容の充実を図るために総 説・解説 (review paper), 原著論文 (original paper), 技術報告 (technical report), トピッ クス（topics）等のジャンルを定めることも合わ せて決めました.

つぎに，編集体制についてです．現在，会誌の 編集は編集委員会と編集委員から選ばれた幹事編
集委員による幹事編集委員会という二重構造で 運営されています. そして, 実質的な編集作業は 編集委員の支援を受けながら主に幹事編集委員 が行っています．全国にちらばる会員が一同に 介して編集委員会を執り行うことが困難である ことからこのような仕組みになっていますが， 毎月のように行われる幹事編集員会に参加し, さまざまな作業を一手に引き受けている幹事編 集委員にとって極めて大きな負担になっている 一方, 編集委員にとってはどうしても会誌編集 への関与が希薄になってしまうという問題が生 じています.

冒頭で述べたように会誌は会の顔であり，そ れを企画編集し発行する編集委員会の責務は重 大です．会の変身に合わせてどのように編集委 員会を組織し運営するかはまだ検討中ですが, 農業情報科学が関係する広範な分野をできるだ け網羅し, 会員の要望の応えると同時に, 最新の 情報をタイミング良く提供できるように機能す る組織を考えています。

さて, 最後になりましたが新雑誌名は，まだ会 の新しい形が確定しておりませんので, とりあ えず「農業情報研究」の名前と巻号を引き継いで 行くこととし, 今年に限っては年 3 回の発行と します. また, 編集体制も当面現状のままとし, どちらも会の新体制が確定した時点で新しいも のに移行することを考えています.ちなみに, 雑 誌編集方針の変更に伴い, 巻末の「投稿規定およ び原稿作成要領」も変更されていますのでご参 照下さい.

今後とも, 会誌編集へのご協力よろしくお願 いいたします. 